\title{
The sensory, physical and nutritional quality profiles of purple sweet potato and soy-based snack bars for pregnant women
}

\author{
Yosfi Rahmi, Adelya Desi Kurniawati, Rahma Micho Widyanto, Ayuningtyas Dian Ariestiningsih, \\ Addien Zahratul 'Aisyi Al Farahi, Annisa Nafilata Ruchaina, Evita Virginia Sihombing, \\ Fanny Bella Istira, Izzatun Nafsiyah, Katarina Dian Permatasari, Ririk Dwi Anjani, \\ Stephani Anggita Yuli Maharani Simanjuntak, Yunda Aulia Rahma
}

Department of Nutrition, Faculty of Medicine, Universitas Brawijaya, Malang, Indonesia

\begin{abstract}
Background: The deficiency of energy, protein, and other beneficial nutrients during pregnancy causes chronic energy deficiency (CED). This condition increases the chance of having babies with low birth weight (LBW) and various other health problems. To meet these nutritional needs, supplementary feeding is necessary in the form of snack bar, using local food ingredients, such as purple sweet potato and soybean (PSPS). This study determines the differences in a few aspects of PSPS snack bar, such as sensory acceptability, physical quality, and nutritional content in several formulations.

Design and Methods: The best three formulations were selected through sensory acceptability by involving 40 panelists and showed the following results P0 (commercial product), P2 (80\% purple sweet potato: $20 \%$ soybean), and P3 (70\% purple sweet potato: $30 \%$ soybean). Furthermore, these formulations were triplicated for further physical color test, the hardness and breaking force, as well as the nutritional analysis that includes both macro and micronutrients.

Results: The results showed significant differences $(\mathrm{p}<0.05)$ in the sensory acceptability, physical quality, nutritional content (except carbohydrate and iron), and antioxidant activity.

Conclusions: In conclusion, snack bars with $70 \%$ purple sweet potato and $30 \%$ soybean gave the best formulation.
\end{abstract}

\section{Introduction}

Energy and nutrient food intake are important factors affecting fetus's health, since pregnant women are prone to experiencing malnutrition. This is because of the increased nutritional requirements needed for the growth and development process of the fetus. The continuous deficiency of energy and protein intake in pregnant women cause chronic energy deficiency (CED), making them four times susceptible to having babies with low birth weight
(LBW), which is prevalence in Indonesia (11.1\%). ${ }^{1}$ Pregnancy condition causes many changes in women's bodies, which include: i) nausea and vomiting, due to the increase in human chorionic gonadotrophin (HCG) hormone, ii) hyperglycemia, due to the synthesis of human placental lactogen and growth hormone, iii) constipation, due to an increase in progesterone hormone and lack of consumption of insoluble dietary fiber, iv) calcium deficiency, caused by its insufficient amounts in supporting fetal growth, v) pre-eclampsia, due to an increase in free radicals, and vi) anemia, due to deficiency in iron and folic acid. ${ }^{2}$ Therefore, a special dietary arrangement is needed to cope with the changes and meeting the nutritional needs through the provision of energy dense foods, high in macro and micronutrients, as well as low in sugar.

One of the methods for meeting the nutritional needs of pregnant women is through supplementary feeding. This is suggested to contain local food-based, which are made from readily available and accessible ingredients, such as the purple sweet potato. The research conducted in Malang Regency stated that farmers always harvest sweet potatoes once in a week, since it is a food with high carbohydrate and low protein content. ${ }^{3}$ Therefore, other foods that are high in protein, such as soybeans are needed to balance the nutritional content, and also overcoming the lack of energy in pregnant women. Purple sweet potato and soybean are potential ingredients for making functional food. They contain natural antioxidants, namely, anthocyanins, beta carotene, isoflavones; rich in micronutrients content like calcium, iron, folic acid; and total food fiber. ${ }^{3,4}$ Regarding the manufacture of snack bars, soybean add value to the physical quality of the products, such as solidity and compactness, because of their hard and crunchy texture property. Besides, the nutrients in purple sweet potatoe and soybean (PSPS) are also expected to help pregnant women maintain the digestive tract's health, control blood sugar, fight free radicals, obtain enough calcium for fetal growth, much folic acid for erythropoiesis and anemia.

Snack bar is an alternative food made from cereals, which is

Significance for public health

Pregnant women are prone to experiencing malnutrition due to the increase nutritional requirements needed, and some changes taking place in the body. One of the methods in meeting these nutritional needs is through supplementary feeding. The snack bar is an alternative food in the form of rods made from cereals, which is relatively practical, easy to obtain, serve and consume. These criteria make snack bars a suitable food with high functional value. Utilizing local food ingredients, such as purple sweet potatoes and soybeans (PSPS) improve snack bars' quality. This study shows the differences in a few aspects of PSPS snack bar for pregnant women, such as sensory acceptability, physical quality, and nutritional content in several formulations. 
relatively practical, and easy to obtain, serve and consume. These criteria make it a suitable snack with high functional value. Currently, snack bars and their varieties are made by utilizing local food ingredients, such as purple sweet potato and soybean. The processing, such as steaming and roasting reduce their fiber, iron, and antioxidant activity. ${ }^{5}$ Therefore, in making the snack bar, no peeling has to be carried out. Also, the mixing and processing of several ingredients affect their final result in terms of sensory, physical quality, and nutritional content. Therefore, it is necessary to conduct a test based on these criteria.

\section{Design and Methods}

This research was conducted in two steps, the first was a preliminary or sensory test and a further assessment. The initial test aims to obtain three formulations with the best acceptance. Then the physical quality, proximate analysis, total sugar, water-insoluble dietary fiber, calcium, iron, folic acid, and antioxidant activity tests were carried out in the three best formulations. The preliminary or sensory test gave three formulations with the best acceptance of P0 (commercial snack bar), P2 (80\% purple sweet potato:20\% soybean), and P3 (70\% purple sweet potato:30\% soybean). Each formulation was triplicated and randomized.

The tools used in the manufacture of PSPS snack bars were a $32 \times 32 \times 3 \mathrm{~cm}$ pan, Kenmaster brand scales, Phillips brand mixers, Miyako brand grinders, plastic brushes, Wispro brand gas ovens, oxone brand electric ovens, steamer pans, knives, corns, gloves, basins, flour sieve, spoon, and Rinnai brand gas stove. The major ingredients used were purple sweet potatoes and soybeans variety of Gunung Kawi and Anjasmoro, respectively. The complementary ingredients used were wheat flour from the Bogasari Kunci Biru brand, Filma brand margarine, egg yolk, skim milk, EDNA brand sugar, maltodextrin, and Kapal Layar brand vanilla. The PSPS snack bar Rather like presented in Table 1.

\section{Manufacture of PSPS snack bar}

The manufacture of a snack bar was divided into three parts:

1. Preparation of sweet potatoes

This preparation started with washing, chopping, and steaming the purple sweet potatoes for $10 \mathrm{~min}$, then crushed using a fork and mixer.

2. Preparation of soybeans
This preparation began with cleaning the soybean husks that have been soaked for 6 hours, roasted for 25 mins, and crushed using a grinder.

3. The final stage of making snack bars

The purple sweet potato was mixed with complementary ingredients using a mixer, added with soybeans. The snack bar dough was then printed on a $4 \times 6 \times 0.5 \mathrm{~cm}$ pan and placed in a gas oven at $160^{\circ} \mathrm{C}$ for $30 \mathrm{~min}$.

\section{Sensory test}

Forty moderately trained panelists from the Nutrition Science Program Students, Faculty of Medicine, Universitas Brawijaya were recruited for the sensory test. The sensory quality was measured by using five scales hedonic test $(1=$ very dislike, $2=$ dislike, $3=$ rather like, $4=$ like, and $5=$ very like). There were six formulations of the composition ratio of purple sweet potato with soybean, namely P0 (commercial snack bar), P1 (90:10), P2 (80:20), P3 (70:30), P4 (60:40), and P5 (50:50). The commercial snack bar was chose based on the ingredients. The panelists identified their acceptance of characteristics (color, taste, aroma, and texture) using a score sheet. The acceptability test results were used to obtain the best three formulations using the Effectiveness Index Method.

\section{Physical quality}

The physical quality test was measured in terms of color, hardness, and breaking force of the food product tested in the laboratory. The color test used Color Reader CR-10. The hardness and breaking-force used ASTM D 882 Universal Testing Machine (UTM), Zwick, DO - FB0, 5TS. 2002 type.

\section{Nutritional content}

The nutritional content tests were measured the protein, fat, and carbohydrate content analysis used the Kjeldahl, Soxhlet and different extraction method, respectively. The insoluble dietary fiber (IDF) analysis was conducted using the AOAC enzymatic gravimetric method. The total sugar content was analyzed using the Anthrone technique. The calcium and iron level test used the ICP-OES method with a wavelength of $317.933 \mathrm{~nm}$. The method used to analyze the folic acid content was the Ultra-Performance Liquid Chromatography (UPLC) with a maximum wavelength of $283 \mathrm{~nm}$. The antioxidant activity measurement used the DPPH reagent (2,2-diphenyl-1-picrillhidrazil). The procedure for testing

Table 1. The formulation of purple sweet potato and soybean (PSPS) snack bars.

\begin{tabular}{|c|c|c|c|c|c|}
\hline \multirow[t]{2}{*}{ Ingredients } & \multicolumn{4}{|c|}{ Formulation (g) } & \multirow[b]{2}{*}{ P5 } \\
\hline & P1 & P2 & P3 & P4 & \\
\hline Purple sweet potato & 72 & 64 & 56 & 48 & 40 \\
\hline Soybean & 8 & 16 & 24 & 32 & 40 \\
\hline Wheat flour & 20 & 20 & 20 & 20 & 20 \\
\hline Margarine & 10 & 10 & 10 & 10 & 10 \\
\hline Egg yolk & 30 & 30 & 30 & 30 & 30 \\
\hline Skim milk & 10 & 10 & 10 & 10 & 10 \\
\hline Brown sugar & 4 & 4 & 4 & 4 & 4 \\
\hline Vanilla & 0.5 & 0.5 & 0.5 & 0.5 & 0.5 \\
\hline Maltodextrin & 2 & 2 & 2 & 2 & 2 \\
\hline Sum & 156.5 & 156.5 & 156.5 & 156.5 & 156.5 \\
\hline
\end{tabular}


antioxidant activity was carried out based on the measurement procedure of the Agro and Biomedical Industrial Technology Development Laboratory (LAPTIAB) Agency for the Assessment and Application of Technology (BPPT).

\section{Results and discussions}

\section{Sensory test}

Based on the average panelist assessment as shown in Table 2, the hedonic score for color was 3.52-4.35, 2.72-4.38 for taste, 3.15-4.38 for the aroma, and 2.90-4.15 for texture. The statistical analysis using Kruskal Wallis $(\mathrm{p}<0.05)$ showed that there was a significant difference $(\mathrm{p}=0.000)$ in every parameter. Sample P0 had the highest hedonic score $(4.32,4.38,4.38,4.15$ for color, flavor, aroma, and texture, respectively). The colors of the PSPS snack bars were brown. A non-enzymatic browning reaction, namely the Maillard produces the brown color of snack bars. This change occurs due to the reaction between reducing sugars and amino acids at high temperatures and for a long time. ${ }^{6}$ The palm sugar's caramelization reaction also caused the brown color of the PSPS snack bars. Caramelization form maltol and isomaltol compounds, making an intense aroma and producing a brownish color. ${ }^{7}$ PSPS snack bars had lower acceptance than the commercial snack bar. Based on the physical quality test results, commercial snack bar had a lighter color than the PSPS snack bar. Panelists preferred light-colored snack bar products to the dark.

The taste produced by PSPS snack bars was sweet and savory. These flavors are obtained from the main ingredients (purple sweet potato and soybean) and others (margarine, sugar, egg yolk, skim milk, and maltodextrin). The potatoes added a sweet taste, while the margarine and roasted soybeans added a savory flavor to the PSPS snack bar. In general, soybean have a bitter after-taste due to saponins' presence, however, these is removed by boiling, stripping the husks, and roasting them. Besides, the addition of sugar aimed to improve the taste and extend the snack bars' shelf life. ${ }^{8}$ The cooking process using the palm sugar cause a caramelization reaction, producing a distinctive sweet caramel taste. ${ }^{7}$

The PSPS snack bar had a lower acceptance on the taste parameters than the commercial snack bar. Commercial snack bar uses the addition of vanilla extract. The PSPS snack bar did not use added flavorings and relied more on purple sweet potato and soybeans' natural flavors. This is related to the product target for pregnant women, therefore, limiting the use of food additives. The addition of vanilla extract to commercial snack bar produces the taste that consumers wanted and increase its acceptability. ${ }^{9}$ The PSPS snack bar had a savory aroma and smelled similar to sweet potato. The Maillard reaction and caramelization caused the aroma of the PSPS snack bar. The caramelization reaction produces the caramel scent that increases the preference for the food products. ${ }^{7}$ The Maillard reaction produces aroma compounds, namely furaneol, carbonyl (furfural, hydroxymethylfulfural, and aldehyl), which reduce the unpleasant odor that appears. ${ }^{6}$ Then, 6 hours of soaking process for soybeans was carried out to remove unpleasant odor due to the presence of lipoxygenation enzymes that produces volatile ethyl phenyl ketone compounds. ${ }^{10}$

The PSPS snack bar's acceptability on aroma parameters was lower than the commercial snack bar. The commercial snack bar has a fragrant vanilla aroma due to the addition of vanilla extract. This addition is useful for reducing the unpleasant odor of soybean flour (the raw material for making the commercial snack bar). ${ }^{9}$ The PSPS snack bar had a dense texture, did not break easily, and was crunchy right after cooked, however, is a little mushy after a while due to the water absorption from the environment. The addition of maltodextrin was intended to reduce the mushy texture as it increases the total solids in the baked snack bars and the amount of water that is evaporated. ${ }^{11}$ The PSPS snack bar had lower texture acceptability than the commercial snack bar. The commercial snack bar has a denser texture and crunchier. This is because the total water content of the commercial snack bar is lower than the PSPS snack bar. The lower the water contents in a food product, the higher the crispiness. Also, the addition of rice crispy to the commercial snack bar added the texture needed.

\section{The best formulations of PSPS snack bar}

The three best formulations were obtained, namely, P0, P3, and $\mathrm{P} 2$. P0 has the highest score in the color, taste, aroma, and texture parameter. $\mathrm{P} 0$ is a commercial product that had been marketed to the broader community, therefore, it had better acceptance than PSPS snack bars. There was vanilla extract in the inside of P0, which improved products' taste. ${ }^{9}$ The second best formulation was P3, which was in line with the previous research where the snack bar with $70 \%$ sweet potato and $30 \%$ black soybean formulation had the highest preference level in color, taste, aroma, and texture. ${ }^{12}$ Therefore, it is stated that P3 treatment is marketed than the other PSPS snack bars formulation. The third best formulation was P2, which had a higher value than P3 in the taste parameter, and a lower value on the aroma and color parameter. A food product that has an unattractive color reduces the panelist appetite in attempting the product. ${ }^{13}$

Table 2. Hedonic test result of purple sweet potato and soybean (PSPS) snack bars on various parameter.

\begin{tabular}{|c|c|c|c|c|c|c|c|c|}
\hline \multirow{2}{*}{ Formulations } & \multicolumn{2}{|c|}{ Color } & \multicolumn{2}{|c|}{ Taste } & \multicolumn{2}{|c|}{ Aroma } & \multicolumn{2}{|c|}{ Texture } \\
\hline & Average & Desc. & Average & Desc. & Average & Desc. & Average & Desc. \\
\hline P0 & $4.35 \pm 0.770^{b}$ & Like & $4.38 \pm 0.740^{b}$ & Like & $4.38 \pm 0.667^{\mathrm{b}}$ & Like & $4.15 \pm 0.893^{b}$ & Like \\
\hline Pl & $3.55 \pm 1.037^{\mathrm{a}}$ & Rather like & $2.72 \pm 0.905^{\mathrm{a}}$ & Rather like & $3.15 \pm 0.893^{\mathrm{a}}$ & Rather like & $2.90 \pm 1.081^{\mathrm{a}}$ & Rather like \\
\hline $\mathrm{P} 2$ & $3.52 \pm 0.751^{\mathrm{a}}$ & Rather like & $3.00 \pm 0.847^{\mathrm{a}}$ & Rather Like & $3.32 \pm 0.829^{\mathrm{a}}$ & Rather like & $3.05 \pm 0.904^{\mathrm{a}}$ & Rather like \\
\hline P3 & $3.68 \pm 0.829^{\mathrm{a}}$ & Rather like & $2.98 \pm 0.920^{\mathrm{a}}$ & Rather like & $3.42 \pm 0.813^{\mathrm{a}}$ & Rather like & $3.05 \pm 1.085^{\mathrm{a}}$ & Rather like \\
\hline P4 & $3.58 \pm 0.958^{\mathrm{a}}$ & Rather like & $2.88 \pm 1.067^{\mathrm{a}}$ & Rather like & $3.30 \pm 0.992^{\mathrm{a}}$ & Rather like & $3.08 \pm 1.047^{\mathrm{a}}$ & Rather like \\
\hline \multirow[t]{2}{*}{ P5 } & $3.62 \pm 1.030 \mathrm{a}$ & Rather like & $2.82 \pm 0.984^{\mathrm{a}}$ & Rather like & $3.28 \pm 0.847^{\mathrm{a}}$ & Rather like & $3.18 \pm 1.059^{\mathrm{a}}$ & Rather like \\
\hline & $p=0.000$ & & $p=0.000$ & & $p=0.000$ & & $p=0.000$ & \\
\hline
\end{tabular}

P0 (commercial snack bar); P1 (90\% purple sweet potato : 10\% soybean); P2 (80\% purple sweet potato : 20\% soybean); P3 (70\% purple sweet potato : 30\% soybean); P4 (60\% purple sweet potato : 40\% soybean); P5 ( $50 \%$ purple sweet potato : $50 \%$ soybean); a,bin the same column showed that there was significant differences $(\mathrm{p}<0.05)$ in various parameter (color, taste, aroma, and texture). 


\section{Physical quality}

The physical quality was described by the value of color parameters ( $\left.\mathrm{L}, \mathrm{a}^{*}, \mathrm{~b}^{*},{ }^{\circ} \mathrm{Hue}\right)$, hardness, and breaking force are shown in Table 3 . The statistical analysis showed no significant difference in $\mathrm{L}, \mathrm{a}^{*}$, and ${ }^{\circ}$ Hue parameters $(\mathrm{p}>0.05)$. However, there was a significant difference $(p<0.05)$ in $b^{*}$ value, hardness, and breaking force between all formulations.

In the color parameter, there are values for $\mathrm{L}, \mathrm{a}^{*}, \mathrm{~b}^{*}$, and ${ }^{\circ} \mathrm{Hue}$. The L value indicated brightness color level; the higher the $\mathrm{L}$ value, the brighter the sample ( $\mathrm{a}^{*}$ value indicated red-green chromatic). When it is positive, the sample color tends to be red, and when negative, it tends to be green ( $b *$ value showed blue-yellow chromatic). ${ }^{14}$ oHe value represented the degree of visual color that is visible. There was a difference in the $b^{*}$ value, while there was none in the $\mathrm{a}^{*}$ value. This was observed by color testing's method indicating brownish yellow on the outer surface of the sample, due to the roasting process. In contrast, the inside of the sample was purple due to sweet potato used in P2 and P3 that was not measured by the tool. $\mathrm{P} 0$ has the highest $\mathrm{L}$ value, i.e., the brightest compared to P2 and P3 because there was no addition of purple sweet potatoes and soybeans as ingredients, which affect the formation of brownish color on the snack bar, resulting from the Maillard reac- tion. Hardness is one of the physical properties of food products that affect consumer acceptance of the product. The significant differences in the hardness parameter of $\mathrm{P} 0, \mathrm{P} 2$, and $\mathrm{P} 3$ are shown in Table 3. These differences were determined by several conditions, such as the material composition's characteristics, the substances contained in the ingredients, and the processing. The hardness levels ranged from the largest to the smallest as follows P0, P3, and P2.

The steaming process of sweet potato reduced the hardness level, because it increases the snack bar dough's moisture content to become softer. Based on this, the large amount of purple sweet potato used affected the high value of water content, while the sample's hardness was getting smaller. ${ }^{15}$ There is no purple sweet potatoes at $\mathrm{P} 0$, therefore, it had the greatest hardness value. The use of chopped soybeans also affected this factor. A large number of soybeans in the dough made the hardness of the sample increased. Breaking force is related to the pressure in an attempt to break the product, and it also correlated with hardness. The harder the product was, the greater the breaking-force value. The difference was in the principle of testing. Hardness is known by determining the maximum force required to cut through the sample until it reached its base. While the breaking-force test was carried

Table 3. Physical quality test result of purple sweet potato and soybean (PSPS) snack bars on various parameter.

\begin{tabular}{|c|c|c|c|c|c|c|c|}
\hline Formulations & & & & & Hardness & Breaking & Figure \\
\hline & L & $a^{*}$ & $b^{*}$ & ${ }^{\circ}$ Hue & & & \\
\hline $\mathrm{P} 0$ & 42.867 & 19.233 & 24.700 & 51.756 & 30.180 & 7.864 & \\
\hline P2 & 37.567 & 16.800 & 17.134 & 45.536 & 10.970 & 2.740 & \\
\hline P3 & 35.400 & 17.333 & 16.667 & 43.843 & 19.000 & 4.740 & \\
\hline
\end{tabular}

Formulations P0, P2, and P3 = proportion of purple sweet potato:soybean; P0 (commercial product), P2 (80\% purple sweet potato : 20\% soybean), P3 (70\% purple sweet potato : 30\% soybean).

Table 4. Nutritional content of purple sweet potato and soybean (PSPS) snack bars.

\begin{tabular}{lccc} 
Parameters & & Mean \pm SD & P3 \\
Protein (\%) & $23.66 \pm 1.07$ & $10.53 \pm 0.24$ & $13.28 \pm 1.01$ \\
Fat (\%) & $24.73 \pm 0.59$ & $18.57 \pm 1.95$ & $18.29 \pm 0.79$ \\
\hline Water (\%) & $8.05 \pm 0.10$ & $30.75 \pm 0.74$ & $27.99 \pm 1.97$ \\
Ash (\%) & $2.40 \pm 0.08$ & $2.14 \pm 0.07$ & $2.38 \pm 0.01$ \\
\hline Carbohydrate (\%) & $41.16 \pm 1.63$ & $38.01 \pm 1.29$ & $38.06 \pm 1.17$ \\
Insoluble dietary fiber (\%) & $24.39 \pm 1.59$ & $17.70 \pm 0.28$ & $19.34 \pm 1.68$ \\
Total sugar (\%) & $24.46 \pm 1.79$ & $10.82 \pm 0.25$ & $10.10 \pm 0.44$ \\
Iron (mg/100 g) & 5.58 & 5.30 & 7.33 \\
\hline Calcium $(\mathrm{mg} / 100 \mathrm{~g})$ & $268.85 \pm 28.46$ & $313.46 \pm 6.37$ & $366.71 \pm 22.93$ \\
Folic acid $(\mu \mathrm{g} / 100 \mathrm{~g})$ & $\mathrm{ND}$ & $132.36 \pm 27.09$ & $222.54 \pm 19.89$ \\
\hline IC 50 (ppm) & 13318 & 6041 & 5914
\end{tabular}

P0 (commercial snack bar); P2 (80\% purple sweet potato : 20\% soybean); P3 (70\% purple sweet potato : 30\% soybean); ND, not detected. 
out by ascertaining the maximum force required until the sample breaks. ${ }^{16}$ The snack bar's breaking force was related to the percentage of water content and the characteristics composition of the ingredients used. ${ }^{17}$ The PSPS snack bar (P2 and P3) had higher water content than that of commercial (P0), shown in Table 4, because purple sweet potatoes were one of the essential ingredients, producing the soft texture. ${ }^{18}$ The value of water content was inversely proportional to the value of breaking force. The higher the water content in the sample, the smaller the breaking-force value.

\section{Nutritional content}

The results of the nutrient content test on the PSPS snack bar were shown in Table 4, and were statistically analyzed using SPSS software with 95\% Confidence level. Statistical analysis showed that there was a significant difference in all the groups $(\mathrm{p}<0.05)$ for the carbohydrate, protein, fat, and insoluble dietary fiber (IDF) parameters. Sample P0 had the highest macronutrient content for every parameter with $23.66 \%$ protein, $24.73 \%$ fat, $41.16 \%$ carbohydrate, $24.46 \%$ total sugar, and $24.39 \%$ IDF.

Statistical analysis result showed a significant difference in all the groups $(\mathrm{p}<0.05)$ for the mineral and vitamin contents (iron, calcium, folic acid). Sample P3 had the highest iron, calcium, and folic acid concentration in 100 grams of the samples. Sample P3 contained $7.33 \mathrm{mg}$ of iron, $366.71 \mathrm{mg}$ of calcium, and $222.54 \mu \mathrm{g}$ of folic acid. The protein content in P2 and P3 is lower than that of $\mathrm{P} 0$, due to the differences in their ingredients. The contributors of protein content in P0 were soy flour and puff, while those in P2 and P3 were soybeans, eggs, and skim milk flour. The decrease in protein content was affected by the heating during the kneading process, known as the Maillard reaction when roasting above $115^{\circ} \mathrm{C}$. The Maillard reaction caused the release of protein amine groups, i.e., the amount of amines was swapped in the proximate analysis. ${ }^{19} \mathrm{P} 3$ has a higher protein content because it contained higher soybean than $\mathrm{P} 2 .{ }^{18}$ The fat content of $\mathrm{P} 0$ was higher because the percentage of soy flour used was $30 \%$ higher than that of soybeans in P2 and P3. Soy flour has more fat content (20.6 grams in 100 grams) than soybeans (17.2-18.6 grams in 100 grams). ${ }^{20} \mathrm{P} 3$ contained more soybeans than P2, however, had less fat content because of the release of fat molecules when soaking soybeans. ${ }^{21}$ P0 had higher carbohydrate content due to the addition of other raw materials, namely dried pineapple and papaya. ${ }^{20} \mathrm{P} 2$ and P3 contained purple sweet potato as carbohydrates contributor (16.582-19.611\% in 100 grams) with twice the amount of soybeans. The percentage of purple sweet potato in P2 was more significant than in P3, however, the carbohydrate content in P2 was lower than in P3. This occurred due to the influence of the purple sweet potatoes' steaming process, which reduce carbohydrate levels. $^{22}$

Snack bar products have not been registered in the Indonesian National Standard (INS). Therefore, the PSPS snack bar is compared to the USDA Food Composition Database Standard Reference 25048, on Nutri-Gain Fruit and Nut Bar. And the results obtained were: $9.38 \%$ higher protein, $10.93 \%$ higher fat, and $64 \%$ lower carbohydrate content. ${ }^{23}$

The IDF content of P0 (24.39\%) was higher than the P3 (19.34\%) and P2 (17.70\%) sample. Significant differences in all the samples were listed in Table 4 . The differences in the use of the main ingredient in the commercial product (P0) and PSPS snack bar contributed to the significant differences in the statistical analysis. P0 used soybean flour (32\%) as the main ingredient, with the addition of soybean puffs $(17 \%)$ as a commercial snack bar component. The addition of soybeans to the rice puffs contributed to the increased IDF content in the commercial snack bars and insignificant. Soybean flour contains high cellulose, which contributed to the high amount of IDF levels in P0. The dried pineapple and papaya also contributed to the increase of IDF levels in the P0 products. The IDF content in this material did not decrease due to the drying process. ${ }^{24}$ The P3 formulation of the PSPS snack bar has more soybean composition than P2, resulting in higher IDF content. ${ }^{25}$ The soaking process of soybeans at average temperature also affected the increasing IDF levels, which was $1.2-8.2 \%$. This was due to the increased cellulose content and the loss of watersoluble sugar, phytate, minerals, and amylase activity during the immersion process. Although there was no increase in hemicellulose and lignin, the increase in cellulose affected the increasing IDF levels. ${ }^{24}$

PSPS snack bar samples', P2 and P3, have lower total sugar content than P0, shown in Table 4, because they contained low sucrose sweetener, such as maltodextrin and palm sugar, with low sugar content of raw material, such as purple sweet potato. Maltodextrin is an alternative sweetener that improves the PSPS snack bar's texture, because it acts as filler in flour products, and increases viscosity and texture. Maltodextrin in PSPS snack bar was still within the normal limits of good manufacturing practice (GMP) and safe for pregnant women with gestational diabetes mellitus (GDM). Maltodextrin did not increase the total sugar content levels and blood sugar significantly, because it had a low dextrose equivalent $(\mathrm{DE})$ value $(\leq 20)$, which makes it less sweet and tends to be bland. ${ }^{26}$ The use of maltodextrin without other sweeteners in PSPS snack bar manufacturing trials still tasted bland, therefore, it should be combined with other sweetener to maintain product appearance, stability, and provide a sweeter taste. Moreover, another sweetener used in PSPS snack bars is palm sugar that is safe for pregnant women with GDM. Palm sugar does not increase sugar levels drastically compared to granulated sugar. This is because; it has a low glycemic index (35) and lower sucrose content (13.9-74.9\%) than granulated sugar (97.1\%). ${ }^{27}$ Raw materials of PSPS snack bar, Gunung Kawi purple sweet potato, and Anjasmoro soybean, also contributed to the total sugar content of P2 and P3 samples. The purple sweet potato has a low sugar content $(0.4 \%$ in $100 \mathrm{~g}){ }^{3}$ The steaming process of purple sweet potato in PSPS snack bar manufacturing process increased the sugar content in sweet potato compared to its raw material. The soybeans have a relatively high sugar content $(15.08 \%$ in $100 \mathrm{~g})$ and it increased because of the moisture loss in the roasting process. However, purple sweet potato and soybean have a very low glycemic index, they did not increase the blood glucose significantly, and safe for pregnant women with GDM. ${ }^{28}$

The P3 and P2 calcium content was higher than that of P0, while the P3 samples showed the highest $\mathrm{Ca}$ content. The product composition which includes calcium content, soybeans, purple sweet potato, and milk powder played a significant role. The P3 sample had a higher calcium ratio in accordance with the higher soybean ratio. The calcium concentration from soybean was around $227 \mathrm{mg} / 100 \mathrm{~g}^{29}$ while the purple sweet potatoes had 30 $\mathrm{mg} / 100 \mathrm{~g} .{ }^{5}$ The average results between P2 and P3 showed a tendency to increase the proportion of soybeans in making the snack bar's iron level higher. The average iron level of P0 was higher than P2, because the commercial snack bar used soybean in two forms, namely soybean flour and puff, while P2 only used roasted soybeans. The iron levels in P2 and P3 were decreasing. This was caused by the processing or cooking procedures, such as exposure to high temperatures (baked and roasting), reducing the iron level to around $5-40 \%$. This result was similar to the research of Dako et al. with the fortification product of NaFeEDTA, stating that yel- 
low sweet potato cookies experienced iron loss of 3.98-29.4\% after the baking process. ${ }^{5}$ The PSPS snack bar is used as an alternative for meeting iron needs in pregnant women. However, the low content in the PSPS snack bar is necessary to combine it with other food ingredients containing high iron in the form of heme or nonheme, as well as containing vitamin C. ${ }^{30}$

Folic acid is a complex and labile component that is easily analyzed by Ultra Performance Liquid Chromatography (UPLC) with its higher significant peak efficiency and shorter time analysis. ${ }^{31}$ The control sample (P0) has "Not Detected" result, due to the point abnormality called "Shoulder Peak". This occurred due to the separation failure between two compounds. And also, when there was an error during injection due to the sample size injected (too big or small), or the solvent was not suitable with the sample (too strong or too weak). ${ }^{32}$ While folic acid content on the P3 was higher than $\mathrm{P} 2$. This occurred because P3 has more soybean than P2, which is known as an excellent source of folic acid that contains $165 \mu \mathrm{g} / 100$ g. ${ }^{4}$ Also, the other components of the PSPS snack bar are rich in folic acid. Sequentially ingredients, such as purple sweet potato, egg yolk, and all-purpose flour contains $12 \mu \mathrm{g}, 25 \mu \mathrm{g}$, and $200 \mu \mathrm{g}$ per $100 \mathrm{~g}$, respectively. The steam method was used to minimize the loss of folic acid on purple sweet potato. This proved that heat is not the leading cause of folic acid loss, however, the water-soluble molecules' diffusion during the boiling and immersion. Natural immersion (water temperature: $30^{\circ} \mathrm{C}$ for $24 \mathrm{~h}$ ) was used to prepare soybean, which cause $32 \%$ loss. ${ }^{33}$ The soybeans, when doubled in size, were roasted until it became brown and dry. This process leads to further loss of folic acid $30-50 \% .{ }^{33}$ After the main ingredients were set and mixed with the other complementary component, PSPS snack bar were ready to be baked at $160^{\circ} \mathrm{C}$ for 30 min. Derivation of folic acid during the baking process transpires because, oxidation changes the chemical structure. Oxidation also occurred during the storage, which leads to the inactivation of folic acid. ${ }^{5}$

\section{Antioxidant activity}

The antioxidant activity test was carried out on the best formulation of the organoleptic test results (P0, P2, P3), using ascorbic acid as a positive control. The results were sorted by the strength, from weakest to the strongest, as follows P0, P2, and P3 with the $\mathrm{IC}_{50}$ value of $13.318 \mathrm{ppm}, 6.041 \mathrm{ppm}$, and $5.914 \mathrm{ppm}$, respectively. In contrast to the snack bar samples, ascorbic acid had a very strong antioxidant activity, with the lowest $\mathrm{IC}_{50}$ value, of $4.51 \mathrm{ppm}$. Furthermore, the linear regression curve of the average DPPH test for snack bar formulations of P0, P2, P3, and ascorbic acid were presented in Figures 1 and 2.

The antioxidant activity of ascorbic acid was powerful $\left(\mathrm{IC}_{50}\right.$ $<50$ ) and much stronger compared to the rest, which was very weak, because the ascorbic acid used was a pure compound compared to the snack bars. P0 had very weak antioxidant activity and

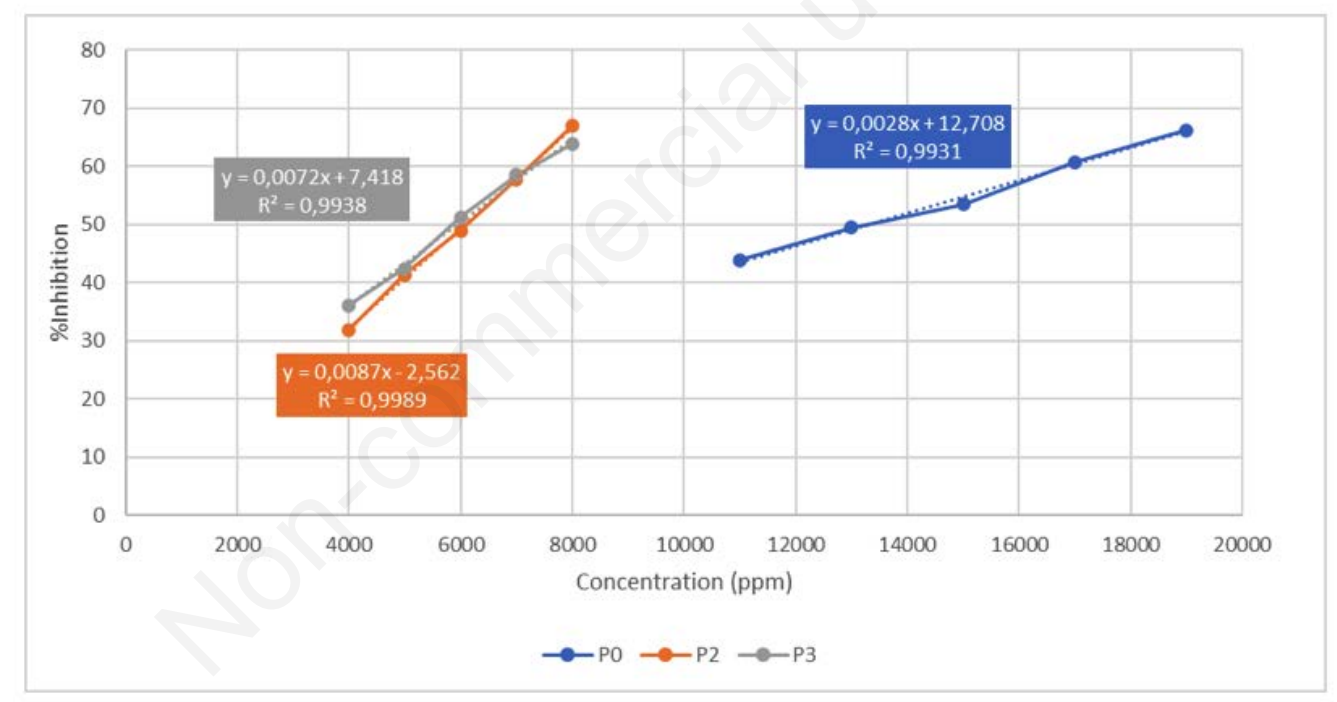

Figure 1. Linear regression curve of the average DPPH test results of P0, P2, P3. P0 (commercial snack bar); P2 (80\% purple sweet potato : $20 \%$ soybean); P3 (70\% purple sweet potato : $30 \%$ soybean).

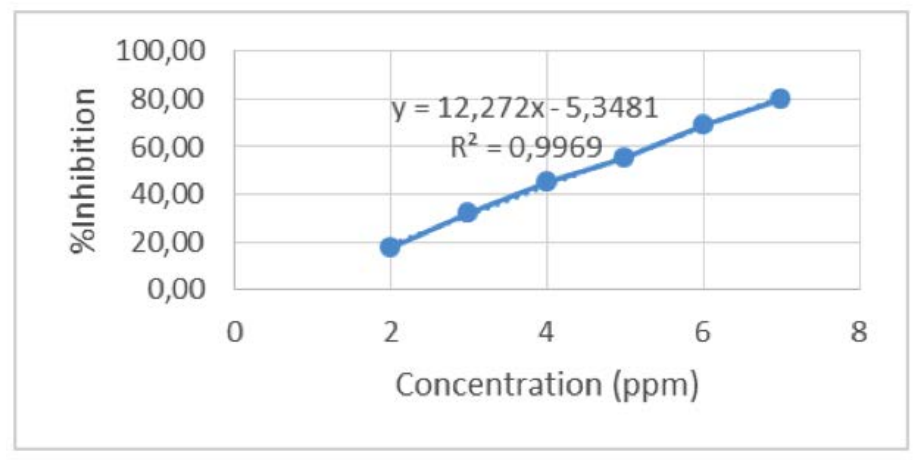

Figure 2. Linear regression curve of the average DPPH test results of ascorbic acid. 
Table 5. Fulfillment percentage of nutritional needs during pregnancy from 1 serving of P3 PSPS snack bar.

\begin{tabular}{|c|c|c|c|c|c|c|c|c|c|c|c|c|c|}
\hline \multirow[t]{2}{*}{ Nutrients 1 ser } & \multirow[t]{2}{*}{ erving P3 (30 g } & gram) I & \multicolumn{2}{|c|}{$\begin{array}{l}\text { Daily needs for } \\
\text { pregnant women } \\
\text { Trimester }\end{array}$} & \multicolumn{3}{|c|}{$\begin{array}{c}\% \text { Fulfillment } \\
\text { Trimester }\end{array}$} & \multicolumn{3}{|c|}{$\begin{array}{c}\text { Additional needs } \\
\text { Trimester }\end{array}$} & \multicolumn{3}{|c|}{$\begin{array}{l}\% \text { Fulfillment } \\
\text { Trimester }\end{array}$} \\
\hline & & 1 & 2 & 3 & 1 & 2 & 3 & 1 & 2 & 3 & 1 & 2 & 3 \\
\hline Protein (g) & 4.43 & 61 & 70 & 90 & 7.3 & 6.3 & 5 & 1 & 10 & 30 & 443 & 44.3 & 14.8 \\
\hline Fat $(g)$ & 6.1 & & \multicolumn{2}{|l|}{64.8} & \multicolumn{3}{|c|}{9.4} & \multicolumn{3}{|c|}{2.3} & \multicolumn{3}{|c|}{265} \\
\hline Carbohydrate (g) & 12.7 & 375 & 390 & 390 & 3.4 & 3.2 & 3.2 & 25 & 40 & 40 & 50.8 & 31.8 & 31.8 \\
\hline Calcium (mg) & 110 & & & 1200 & & & 9 & & & 200 & & & 55 \\
\hline Folic acid ( $\mu \mathrm{g})$ & 33.67 & & \multicolumn{2}{|l|}{600} & \multicolumn{3}{|c|}{5.6} & \multicolumn{3}{|c|}{200} & \multicolumn{3}{|c|}{16.84} \\
\hline Iron (mg) & 2 & 18 & 27 & 27 & 11.1 & 7.4 & 7.4 & 0 & 9 & 9 & - & 22.2 & 22.2 \\
\hline $\operatorname{IDF}(\mathrm{g})$ & 5.8 & 22.6 & 23.4 & 23.4 & 26 & 25 & 25 & 2 & 2.7 & 2.7 & 290 & 215 & 215 \\
\hline Total sugar (g) & 3 & & $<25$ & & \multicolumn{3}{|c|}{$<12$} & \multicolumn{3}{|c|}{$<6$} & \multicolumn{3}{|c|}{$<6$} \\
\hline
\end{tabular}

a significant difference with $\mathrm{P} 2$ and $\mathrm{P} 3$ because, it does not contain purple sweet potato compared to others, which was made from soy flour, soy puffs, and dried fruits. The form of flavonoids in the purple sweet potatoes and soybeans caused very weak antioxidant activity in P2 and P3, because they are often bond to glycoside groups. ${ }^{34}$ Although the purple sweet potatoes were unpeeled, the high temperature and heating duration of steaming and roasting were still directly proportional to the decrease in free radical scavenger compounds, therefore, the antioxidant activity was still getting weaker. ${ }^{35}$ The fresh purple sweet potato steamed for 30 mins experienced a decrease in anthocyanin levels by $42.16 \%$, and the antioxidant activity decreased to a value of $6.28-17.33 \%$. This was caused by the nature of water-soluble anthocyanin compounds that were carried away by water vapor. The decrease in anthocyanin levels and form of glycosylation reduces the free radical scavenging ability of anthocyanins. ${ }^{36}$

In contrast to the existing results $(\mathrm{P} 3>\mathrm{P} 2)$, previous studies showed that the antioxidant activity of purple sweet potato is stronger when compared to soybeans. ${ }^{37}$ This is caused by the differences in purple sweet potatoes and soybeans' antioxidant properties in the processing. Compare to purple sweet potato, the processing increase the isoflavones. The main isoflavones in soybeans are mainly in the form of aglycones (isoflavonoids), which have stronger antioxidant activity than glycone forms. ${ }^{37}$ The heating process makes it easier for the $\alpha$-glucosidase enzyme to grow and convert the bound isoflavones (glycosides) into unbound (aglycones). Soaking and roasting soybean seeds increase isoflavone aglycones, therefore, having a higher antioxidant activity than the glycone form. ${ }^{38}$ Previous studies have shown that heat processing in sweet potato increase the antioxidant activity. It might be due to disruption of the cell wall and liberation of antioxidant compounds from insoluble portions. ${ }^{39}$

The solid form of the sample caused the high $\mathrm{IC}_{50}$ value because, it was difficult to completely dissolve them in methanol. This was also influenced by the high fiber and starch content in the main ingredient. Fiber and starch decrease antioxidant activity by trapping phenolic components through physicochemical interactions between the phenolic and dietary fiber components, affecting the quantity and the ability of phenolic as antioxidants.
Furthermore, the type of phenolic component, which has many hydroxyl groups and contains many hydrophobic domains, makes the interactions stronger. The presence of amylose and amylopectin significantly reduce the phenol content due to its strong interactions with its constituents, particularly with amylose. The linear nature of amylose causes the bonds formation between the starch and phenolic components in the solution to be stronger. Amylopectin's double helix structure also cause phenolic components to be trapped, without chemically interacting with starch, causing lack of phenolic components that capture the 2,2-diphenyl1-pikrilhidrazil (DPPH), and reducing the antioxidant activity. ${ }^{40}$

\section{Implication to pregnant women daily need}

Based on all the variables, the best PSPS snack bar formulation was P3 (70\% purple sweet potato and 30\% soybean). When a pregnant woman (at $2^{\text {nd }}$ trimester) consumes a portion of this formula around 30 grams, it will meet the additional need of $44.3 \%$ protein, $55 \%$ calcium, $16.84 \%$ folic acid, $22.2 \%$ iron, and $215 \%$ IDF as shown in the Table 5. If the PSPS snack bar is taken during the $1^{\text {st }}$ trimester pregnancy, it will help in preventing nausea and vomiting, however, it has not been tested on the targeted customers yet.

\section{Conclusions}

Supplementary feeding is found as an alternative solution against the prevalence of chronic energy deficiency during pregnancy. The use of local food ingredient in the product preparation increases the success of the feeding objectives. The combination of purple sweet potato as local food and soybean, produce nutritious, practical, and easy to consume snack bars suitable for pregnant women. However, further research related to the effectiveness of using this product on the targeted customers needs to be carried out. 
Correspondence: Yosfi Rahmi, Department of Nutrition, Faculty of Medicine, Universitas Brawijaya, Malang, Indonesia, Jl. Veteran Malang, 65145, East Java, Indonesia.

Tel. +62.341569117 - Fax: +62.341564755

E-mail: yosfirahmi79@ub.ac.id

Key words: Snack bar; pregnant women; purple sweet potato; soybean.

Acknowledgement: The authors are grateful to the Department of Nutrition, Faculty of Medicine,, Universitas Brawijaya, Malang, Indonesia, for their kind support and encouragements during this study.

Contributions: All authors contributed equally to this article.

Conflict of interests: The authors have a patent administration pending.

Funding: None.

Ethical approval: This study was approved by the Health Research Ethics Committee, Faculty of Medicine, Universitas Brawijaya, Indonesia, with sensory test No. 224/EC/KEPK-S1-GZ/08/2019.

Conference presentation: Part of this study was presented at the $1^{\text {st }}$ International Nursing and Health Sciences Symposium, November $13^{\text {th }}$ to $15^{\text {th }} 2020$, Brawijaya University, Malang, Indonesia.

Received for publication: 14 January 2021.

Accepted for publication: 10 March 2021.

o Copyright: the Author(s), 2021

Licensee PAGEPress, Italy

Journal of Public Health Research 2021;10:2241

doi:10.4081/jphr.2021.2241

This work is licensed under a Creative Commons Attribution NonCommercial 4.0 License (CC BY-NC 4.0).

\section{References}

1. Syari M, Serudji J, Mariati U. [Peran Asupan Zat Gizi Makroutrien Ibu Hamil terhadap Berat Badan Lahir Bayi di Kota Padang (The role of maternal macronutrient intake of pregnant women on birth weight of babies in Padang City)].[Article in Indonesian]. Jurnal Kesehatan 2015;4:72936.

2. Anggraeny O, Ayuningtyas DA. [Gizi Prakonsepsi, Kehamilan, dan Menyusui (Preconception nutrition, pregnancy and breastfeeding)].[Book in Indonesian]. Malang: UB Press; 2017.

3. Ginting E, Yulifianti R. Jusuf M. Ubi Jalar sebagai Bahan Diversifikasi Pangan Lokal (Sweet potatoes as an ingredient for local food diversification)].[Article in Indonesian]. Pangan 2014;23:194-207.

4. Burssens S, Pertry I, Ngudi DD, et al. Soya, human nutrition and health. In: Yin Y, Fatufe AA, Blachier F (eds) Soya bean meal and its extensive use in livestock feeding and nutrition. InTech; 2011. p. 157-80.

5. Dako E, Negussie R, Gulelat D. Comparison of three sweet potato (Ipomea Batatas (L.) Lam) varieties on nutritional and anti-nutritional factors. Glob J Sci Front Res D Agric Vet 2016;16:1-11.

6. Warsito YAP, Al-baarri AN, Abduh SBM. [Intensitas Kecoklatan, Sifat Antioksidan, dan Goaty Aroma pada Proses Glikasi Whey Susu Kambing dan L-psikosa, L-tagatosa, dan
L-fruktosa (Brownish intensity, antioxidant properties, and goaty aroma on goat milk whey glycation process and L-psychose, L-tagatose, and L-fructose)].[Article in Indonesian]. Jurnal Aplikasi Teknologi Pangan 2014;3:160-3.

7. Tanjung RA, Karo-karo T, Juliatin E. Pengaruh Penambahan Gula Pasir dan Lama Pengeringan terhadap Mutu Gula Semut Nira Kelapa Sawit (Elaesiguineensis, Jacq) (Effect of addition of sugar and drying time on quality of palm nira ants sugar (Elaesiguineensis, Jacq)].[Article in Indonesian]. J Food Life Sci 2018;2:123-32.

8. Ismayasari AA, Wahyuningsih, Paramita O. Studi Eksperimen Pembuatan Enting-enting dengan Bahan Dasar Kedelai sebagai Pengganti Kacang Tanah (Experimental study of making enting-enting with soybean as a substitute for peanuts)].[Article in Indonesian]. Food Science and Culinary Education Journal 2014;3:56-65.

9. Arbaiyah. [Sifat Organoleptik Es Krim dengan Penambahan Lada Hitam (Piper ningrum Linn) (Organoleptic properties of ice cream with addition of black pepper (Piper ningrum Linn)].[Thesis in Indonesian]. Sultan Syarif Kasim State Islamic University. Pekanbaru; 2011.

10. Adriandri RS, Daniardi S, dan Hidayah N. [Identifikasi Komponen Flavor pada Tepung Ubi Jalar, Kacang Hijau, dan Kacang Kedelai sebagai Bahan Baku Produk Snack Bars (Identification of flavor components in sweet potato flour, green beans, and soybeans as raw materials for snack bars products)].[Article in Indonesian]. Proceedings Research Seminar on Various Nuts and Tubers; 2012 Juli 5. Malang, Indonesia. Bogor: Agricultural Research and Development Agency; 2013. p. 340-9.

11. Hindom GV. [Kualitas Flakes Talas Belitung dan Kecambah Kedelai (Glycine max (L) Merill) dengan Variasi Maltodektrin (Quality of belitung taro flakes and soybean sprouts (Glycine $\max (\mathrm{L})$ Merill) with maltodextrin variation)].[Thesis in Indonesian]. Yogyakarta: Atma Jaya University Yogyakarta; 2013

12. Avianty S, Ayustaningwarno F. [Kandungan Zat Gizi dan Tingkat Kesukaan Snack Bar Ubi Jalar Kedelai Hitam sebagai Alternatif Makanan Selingan Penderita Diabetes Melitus Tipe 2 (Nutritional content and level of preference for black soybean sweet potato snack bars as an alternative snack for people with type 2 diabetes mellitus)].[Article in Indonesian]. J Nutr Coll 2013;2:622-29.

13. Santosa I, Andini PW, Endah S. Kajian Sifat Kimia dan Uji Sensori Tepung Ubi Jalar Putih Hasil Pengeringan Cara Sangsari (Study of chemical properties and sensory test of white sweet potato flour result of sangsari drying)].[Article in Indonesian]. Jurnal Chemica 2016;3:55-60.

14. Ekafitri R, Sarifudin A, Surahman N. Pengaruh Penggunaan Tepung dan Puree Pisang Terhadap Karakteristik Mutu Makanan Padat Berbasis-Pisang (Effect of use of banana flour and puree on quality characteristics of banana-based solid foods)].[Article in Indonesian]. Nutrition and Food Research 2013;36:127-34.

15. Shaliha LA, Abduh SBM, Hintono A. Aktivitas Antioksidan, Tekstur, dan Kecerahan Ubi Jalar Ungu (Ipomoea batatas) yang Dikukus pada Berbagai Lama Waktu Pemanasan (Antioxidant activity, texture, and brightness of steamed purple sweet potato (Ipomoea batatas) for various heating times)].[Article in Indonesian]. Jurnal Aplikasi Teknologi Pangan 2017;6:141-4.

16. Muflihati I, et al. Efek Substitusi Tepung Terigu dengan Pati Ketan Terhadap Sifat Fisik Cookies (The effect of substitution of wheat flour with glutinous starch on the physical properties 
of cookies)].[in Indonesian]. Semarang: Faculty of Engineering PGRI University; 2015.

17. Jauhariah D, Ayustaningwarno F. Snack Bar Rendah Fosfor dan Protein Berbasis Produk Olahan Beras (Low phosphorus and protein based snack bars of processed rice products)].[Article in Indonesian]. J Nutr Coll 2013;2:250-61.

18. Rahardjo LJ, Bahar A, Adi AC. Pengaruh Kombinasi Kacang Kedelai (Glycine Max) dan Kacang Tunggak (Vigna Unguiculata (L) Walp.) yang Diperkaya Biji Nangka (Artocarpus Heterophyllus) Terhadap Daya Terimadan Kadar Protein Snack bar (Effect of combination of soybeans (Glycine Max) and Cowpeas (Vigna Unguiculata (L) Walp.) enriched with jackfruit seed (Artocarpus heterophyllus) on acceptability and protein content of snack bars)].[Article in Indonesian]. Amerta Nutrition 2019;3:71-77.

19. Widiawati A, Anjani G. Cookies Tepung Beras Hitam Dan Kedelai Hitam Sebagai Alternatif Makanan Selingan Indeks Glikemik Rendah (Black rice and black soybean flour cookies as an alternative to a low glycemic index snack)].[Article in Indonesian]. J Nutr Coll 2017;6:128-37.

20. Sari DYE, Angkasa D, Swamilaksita PD. [Daya Terima dan Nilai Gizi Snack Bar Modifikasi Sayur dan Buah Untuk Remaja Putri (Acceptability and nutritional value of vegetable and fruit modified snack bars for young women)].[in Indonesian]. Jakarta: Esa Unggul University; 2017.

21. Augustyn GH, Moniharapon E, Resimere S. Analisa Kandungan Gizi Tepung Kacang Gude Hitam (Cajanuscajan) Dengan Beberapa Perlakuan Pendahuluan (Analysis of nutritional content of black gude bean flour (Cajanuscajan) with several preliminary treatments)].[Article in Indonesian]. J Agric Technol 2017;6:27-32.

22. Meilita Q. Pengaruh Suhu Dan Waktu Pemanggangan Dan Perbandingan Tepung Kacang Merah Dengan Tepung Talas Terhadap Karakteristik Cookies (The effect of temperature and roasting time and comparison of red bean flour and taro flour on the characteristics of cookies)].[in Indonesian]. Bandung; Pasundan University; 2019.

23. Lawalata VN, Maatoke I, Tetelepta G. Karakteristik Kimia Food Bar Puree Pisang Tongka Langit (Musa trogodytarum) dengan Penambahan Kenari (Canarium indicum L.) (Chemical characteristics of food bar puree banana (Musa trogodytarum) with the addition of walnuts (Canarium indicum L.)].[Article in Indonesian]. J Agric Technol 2019;8:48-52.

24. Liu X, Zhao J, Li Y, et al. Enrichment of soybean dietary fiber and protein fortified rice grain by dry flour extrusion cooking: The physicochemical, pasting, taste, palatability, cooking and starch digestibility properties. RSC Advs 2018;8:26682-90.

25. Ratnaningsih, N, Ginting E, Adie MM, et al. Sifat FisikoKimia Dan Kandungan Serat Pangan Galur-Galur Harapan Kedelai (Physico-chemical properties and fiber content of hope soybean streaks)].[Article in Indonesian]. Jurnal Penelitian Pascapanen Pertanian 2018;14:35-45.

26. Ramadhani D. Pengaruh Konsentrasi Maltodekstrin dan Putih Telur Terhadap Karakteristik Minuman Serbuk Buah Naga Merah (Hylocereuspolyrhizus) (Effect of maltodextrin and egg white concentration on characteristics of red dragon fruit powder drink (Hylocereuspolyrhizus)].[Thesis in Indonesian].
Bandung: Faculty of Engineering, Pasundan University; 2016. 27. Joseph GH. Layuk P. Pengolahan Gula Semut dari Aren (Sugar processing ants from sugar palm). Buletin Palma 2012;13:605.

28. Canadian Diabetes Association. Clinical practice guidelines for the prevention and management of diabetes in Canada: Glycemic index food guide. Canadian Diabetes Association; 2013. Accessed: 2019 April 15. Available from: https://guidelines.diabetes.ca/docs/patient-resources/glycemic-index-foodguide.pdf

29. Purnasari G, Briawan D, Dwiriani CM. Asupan Kalsium dan Tingkat Kecukupan Kalsium pada Ibu Hamil di Kabupaten Jember (Calcium intake and adequacy level of calcium in pregnant women in Jember Regency)].[Article in Indonesian]. Media Kesehatan Masyarakat Indonesia 2016;12:261-8.

30. Wijiindyah A, Anwar S, Susetyorini SH. Pemanfaatan Tepung Daun Kelor (Moringaoleifera Lamk) dengan Pretreatment Asam dan Tepung Ikan Lele Terhadap Pemulihan Anemia Secara In Vivo (Utilization of Moringaoleifera Lamk leaf flour with acid pretreatment and catfish flour against anemia recovery by in vivo)].[Article in Indonesian]. Jurnal Gizi Klink Indonesia 2012;9:73-9.

31. Jastrebova J, Strandler HS, Patring J, et al. Comparison of UPLC and HPLC for analysis of dietary folates. Chromatohraphia 2011;73:219-25. Erratum in: Chromatographia 2011;73:613.

32. Hawkins C, Dolan J. Understanding split peaks. LC GC Europe 2014;16:1-4.

33. Mo H, Kaliruoto S, Piironen V, et al. Effect of soybean processing on content and bioaccessibility of folate, vitamin B12 and isoflavone in tofu and tempe. J Food Chem 2013;141:2418-25.

34. Fukumoto LR, Mazza G. Assessing antioxidant and prooxidant activities of phenolic compounds. J Agric Food 2000;48:3597604.

35. Anggraeni FD, Santoso U, Cahyanto MN. Aktivitas Antioksidan Ekstrak Berbagai Hasil Olahan Ubi Jalar (Antioxidant activity of various processed sweet potatoes extract)].[Article in Indonesian]. Jurnal Teknologi Pangan 2015;6:43-50.

36. Zhao CL, Chen ZJ, Bai XS, et al. Structure-activity relationships of anthocyanidin glycosylation. Mol Divers 2014;18:687-700.

37. Sun JM, Sun BL, Han FX, et al. Rapid HPLC method for determination of 12 isoflavone components in soybean seeds. Agric Sci China 2011;10:70-7.

38. Zaheer K, Akhtar MH. An updated review of dietary isoflavone: nutrition, processing, bioavailability and impacts on human health. Crit Rev Food Sci Nutr 2017;57:1280-93.

39. Kim MY, Lee BW, Lee HU, et al. Phenolic compounds and antioxidant activity in sweet potato after heat treatment. J Sci Food Agric 2019;99:6833-40.

40. Quirós-Sauceda AE, Ayala-Zavala JF, Sáyago-Ayerdi SG, et al. Added dietary fiber affects antioxidant capacity and phenolic compounds content extracted from tropical fruit. J Appl Bot Food Qual 2014;87:227-33. 